Intake of Southeast Asian (SEA) refugees in France is importantly connected both to its general refugee intake policy and to the history of France's involvement in Southeast Asia over the past century. Of more recent import was the wave of refugees living in Vietnam after the defeat of France at Diem Bien Phu 1954. This stream of migration established an important base of SEA nationals in France at the time of the beginning of the large refugee wave after the fall of the Saigon regime in 1975.

During the 1950s, France created the legal structure to establish the Office française de protection des réfugiés et apartides (OFPRA), which governs all official decisions with regard to the determination of refugee status within France for every such application. Decisions of the Office of Director of OFPRA with regard to the determination of status of refugee for every such applicant are binding without further governmental intervention. Negative decisions may be appealed to an autonomous body, Commission de Recours, which is composed of three representatives; it is chaired by a member of the state counsel (Conseil d'Etat), a representative of the council of OFPRA, and a representative of the French delegation of UNHCR.

In the case of SEA refugees, the determination of refugee status has occurred categorically, with relatively few such applications requiring direct reference to the office of the Director of OFPRA. ${ }^{1}$

As a result of the interpretation of French legislation, the UNHCR exercises three principal roles with regard to refugee resettlement:

- surveillance, involving both administrative overview of the procedures for handling refugee status claims as well as substantive matters involving the status of the claimant;

- serving on an advisory council to the French government with regard to all matters of the government's role in refugee selection, determination, and resettlement;

- adjudication of all appeals from OFPRA.

The interests of the UNHCR delegation with regard to SEA acceptance and resettlement have been persistent and far-ranging. With regard to refugee selection and quota, the delegation continuously presses for augmentation. A notable recent representation resulted in a supplementary quota being established for the year 1982, composed of 6,000 Cambodians who have been long-term residents in Thai camps. In an effort to provide refugee arrivals with the rudiments of spoken French, UNHCR has contributed to the establishment of language classes operated by the NGO "Ecoles sans Frontières" at three campsites in Southeast Asia, where refugees attend classes offered daily while they await final clearance for transit to France.

The UNHCR delegation has also succeeded in making joint contributions with the government of France for special programs of assistance to the establishment of small businesses and for emergency assistance to refugees in becoming established, the latter program especially directed to refugees other than those of SEA origin. Of special significance to SEA refugees is the implementation of the delegation's recommendation for a single refugee identity card which permits access to all services including the right to work.

\section{Selection of Refugees}

It has been the policy of the French government to select SEA refugees on the basis of a yearly quota with the following priorities:

1. The unification of families (children, close relatives).

2. Administrative or military service with the French government.

Of less significance but still important has been the knowledge of the. French language and possibly some prior acquaintance with French nationals. Since 1975, the quotas established by the government have been set at approximately 12,000 SEA refugees per year. As noted above, the quota for 1982 has been augmented to include a supplement of 6,000 Cambodians of long-term duration in Thai camps. This special supplement is unlikely to be renewed for 1983 .
Unofficially, both governmental officials and NGO representatives estimate that the actual number of arrivals to France between 1975 and 1981 should be reckoned between 100,000 and 120,000 persons. The disparity between official and unofficial figures is explained by the inclusion of persons who arrive originally as students or under other auspices who join the refugee community. Furthermore, refugees arrive in France often from intermediate destinations elsewhere in Europe or the Middle East. ${ }^{2}$

While refugees enjoy protected status in France, assured both by the French government and the UNHCR, there is considerable concern both on the part of the French government and of the refugee community, to eliminate the official label "refugee" as quickly as possible. Accordingly, SEA refugees have the unique opportunity (not afforded to other refugees) of becoming French nationals (i.e., citizens), after the first year following arrival.

\section{Refugee Resettlement System}

The French government has arranged a

Official SEA Refugee Arı by Ethni

\begin{tabular}{|c|c|c|c|c|}
\hline Origina & 1975-76 & 1977 & 1978 & \\
\hline $\begin{array}{l}\text { Lao } \\
\text { Thai } \\
\text { Hmong }\end{array}$ & $\begin{array}{c}28 \% \\
11 \\
4\end{array}$ & $\begin{array}{c}24 \% \\
9 \\
15\end{array}$ & $\begin{array}{c}22 \% \\
1 \\
13\end{array}$ & 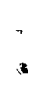 \\
\hline Cambodian & 45 & 32 & 34 & \\
\hline Vietnamese & 11 & 19 & 29 & \\
\hline Chineseb $^{b}$ & 1 & 1 & 1 & \\
\hline Other & * & * & * & \\
\hline Total & $100 \%$ & $100 \%$ & $100 \%$ & \\
\hline Number & 19,128 & 11,468 & 12,402 & 1 \\
\hline \multicolumn{5}{|c|}{$\begin{array}{l}\text { Source: France Terre d'Asile } \\
\text { Notes: aCombination of Ethnic and Geogra } \\
\text { bself-described Chinese. Speakers of } \\
\text { in other origin counts. }\end{array}$} \\
\hline "Less than o & ne percent & & & \\
\hline
\end{tabular}




\section{ance}

\author{
zel Lanphier
}

highly elaborate and efficient system of service delivery to refugees immediately following their arrival in France. This arrangement was established in 1975 and has continued with only minor modifications since then.

A national committee (Comité National d'Entraide, Franco-vietnamien, Francocambodgien, Franco-laotien), funded by the Secretary of State for social action and the Ministry of Labour, as well as by private sources, to initiate and coordinate more activities of resettlement of refugees from SEA origins, hosts governmental bodies with NGOs.

The committee has three principal functions:

1. overview responsibility for the selection of potential refugees to arrive in France;

2. recommending to the French government legal and administrative measures to assist in the resettlement of refugees;

3. co-ordinating the activities of the several NGOs in order to facilitate the re-adaptation process of refugees. ${ }^{3}$

ivals, France, 1975-1981,

ic Origin

$\begin{array}{cccc}1979 & 1980 & 1981 & \text { TOTAL } \\ 14 \% & 20 \% & 21 \% & 21 \% \\ 2 & 4 & 2 & 5 \\ 11 & 8 & 5 & 9 \\ 28 & 38 & 46 & 38 \\ 45 & 30 & 26 & 26 \\ * & * & * & 1 \\ * & * & * & \bullet \\ 100 \% & 100 \% & 100 \% & 100 \% \\ -5,378 & 12,001 & 12,290 & 82,667\end{array}$

phic

some Chinese dialect much higher; included
By far, the most extensive activity of the national committee has involved the coordination of the reception and resettlement services offered by the several NGOs.

\section{Resettlement Centres}

Most refugees are sent to one of approximately 75 resettlement centres located in 51 different Départements in France, all outside the metropolitan region of Paris. Such assignments are co-ordinated by France Terre d'Asile but result from collaborative arrangements with the centres, each of which is independently directed although funded by the Ministry of National Solidarity.

These centres are all temporary lodgings, converted usually from quarters originally designated for other uses; refugees may spend between four to six months at such a centre, during which time nearly all resettlement services are channelled through those auspices. Orientation and language classes are held either on the premises of the centre or nearby in the local community. Each centre has its own staff of counsellors who provide both initial orientation to each refugee family as well as specific counselling according to the particular needs (the location of family members, eligibility for training programs, plans for employment and permanent settlement elsewhere). These centres provide full meals and the basic requirements for family life. Additionally, each refugee receives a weekly allowance of 20 francs (Can. \$4).

The combination of the administrative need for making room for incoming refugees and the interest of the refugee assuming independent life in France results in considerable pressure for the refugee to vacate the centre after four months' residence. If, however, no one in the refugee family has successfully found employment by that time, the stay may be extended an additional two months. Departures are normally con- tingent upon the refugee's having secured both employment and housing.

\section{Individual Solutions}

Refugees may opt for joining close relatives or friends upon arrival without entering the resettlement centres. Such arrangements are made after a brief and somewhat informal undertaking on the part of the sponsor to provide orientation and accommodation for the refugee family under his or her charge. These refugees often require considerable social assistance during their initial month of resettlement. They are assisted basically by two organizations: Service Social d'Aide aux Emigrants (SSAE) and Secours catholique (SOS). Each of these organizations is established in nearly every department and is required to assist every refugee who so applies. Thus, each organization has a full array of resettlement services available, including a cash assistance plan keyed to the level of assistance that would otherwise be supplied by the resettlement centre. Officially, refugees may have access to cash assistance and various social services for a period of three months, followed by one such renewal. Both SSAE and SOS are financed by the Ministry of National Solidarity as well as by private donations. Their work is disproportionately concentrated within the metropolitan region of Paris, where some $80 \%$ of refugees asking for individual solutions locate.

\section{Summary}

SEA refugee intake has been surrounded with a certain ambivalence. Governments and NGOs intend to respect a commitment which they insist is an integral part of the French tradition of refugee reception. In this context, an augmentation of intake is no less necessary as an expression of this very continuity. At the local levels, the resistance appears as a reaction to the continuation of a refugee influx which was presumed to be tapering. This tension promoted a committee of NGOs to publish a detailed brochure, ". . . alors ce n'était pas fini?" (". . . well, has not all of this already finished?") This brochure, directed to an audience of local governmental administrators, politicians, and public leaders, argues that the persistent pressures in Southeast Asian refugee camps leave France no choice but to revitalize their refugee reception acti-

(Continued on p. 8) 
Recent Resettlement

(Continued from p. 6)

vities: the urgency of resettlement overrides concern over job placement and public resistance.

There is no quick or easy resolution of the issue of rate of refugee intake and resettlement. It is possible for local prefectures and governments to resist effectively alteration of refugee intake in their communities by not allowing resettlement centres to offer the necessary services. With the increased autonomy being allowed local départements under the Socialist government in France, implementation must take the form of persuasion rather than coercion. Yet nearly all refugees arriving in France will be rejoining relatives who are already established; thus the burden for NGOs who were previously the sole providers of resettlement services would be lightened. This "sharing of the burden" is limited, however, as increasing proportions of arrivals have opted for resettlement centres rather than individual solutions for the first 4-6 months following their arrival in France. Still, representations by refugees already established for the selection of their relatives will certainly increase in number and urgency over the coming months. It is apparent that the government's option to stretch out the intake but not to reduce the promised supplement represents the only feasible compromise in a situation that could become increasingly politicized. Such an eventuality is viewed by all parties with apprehension.

France has attempted to integrate refugees into the ongoing structure of French society with a very minimum of accommodation to the cultural particularities of the refugee groups so concerned. Correspondingly, political leaders wish to avoid an escalation of refugee resettlement into a political issue which could divide the French population into ethnic cleavages. Until recently, governments have been rather successful in the resolution of such issues by informal means, thereby minimizing such cleavages. In the present case, however, the delicate and careful treatment of SEA refugee intake in the near future remains a capital challenge both to political leaders and to social agencies in their attempts to assure an adequate delivery of services, especially to new arrivals.

C. Michael Lanphier is a professor of Sociology at York University. He is associated with the Ethnic Research program at the university.

\section{Canada's Aid to Refugees}

\section{To UNHCR}

For Pakistan (Afghan refugees)

For Thailand $(600,000$ refugees)

For Central America (El Salvadoran, Guatemalan and Nicaraguan refugees)

For Africa:

Ethiopia (to aid resettlement of returnees)

Somalia (Ethiopian refugees)

Sudan (Ethiopian refugees)

TOTAL

\section{To International Red Cross}

For humanitarian relief programs in Thailand and Africa

Thailand (for refugee relief programs along the Thailand/Kampuchea border)

Africa (for civilians displaced as a result of numerous armed conflicts)

TOTAL

$\begin{array}{r}\text { Funds Donated } \\ \$ 5 \text { million } \\ 1 \text { million } \\ 2 \text { million } \\ 2 \text { million } \\ 1 \text { million } \\ 1 \text { million } \\ \hline \$ 12 \text { million }\end{array}$

1 million

1 million

$\$ 2$ million

\section{To UNICEF}

For Ethiopia (for expanded immunization program for young children and pregnant women in refugee settlements)

500,000

For Lebanon (for relief supplies - medicines, blankets and the water supply)

500,000

TOTAL

$\$ 1$ million

In addition, Canada is providing $\$ 50,000$ to the League of Red Cross Societies (LRCS) for their program of assistance to Vietnamese "boat people" refugees in various Southeast Asian countries. Canada is also granting $\$ 150,000$ to the International Committee of the Red Cross (ICRC) for its program of assistance for political detainees. The funds to LRCS and ICRC will be provided through the International Humanitarian Assistance (IHA) program of the Canadian International Development Agency (CIDA).

\section{Project Inter-Amicos}

Project Inter-Amicos, founded in May 1982, is a permanent sponsor group under the aegis of the Ottawa-Carleton Immigrant Services Organization (OCISO) (a non-profit, charitable social service organization). The Project has taken on the task of sponsoring, in a continuous but limited fashion, families from Southeast Asian refugee camps in response to the ongoing need for resettlement assistance for Indochinese refugees remaining in the camps, with family reunification cases from the Hong Kong camps being the priority. Project InterAmicos is presently seeking funds and community support to enable them to expand their operations to support the sponsoring of families from Thai and Malaysian camps.

If you require additional information or assistance, please call or write

Project Inter-Amicos, OttawaCarleton Immigrant Services Organization, 425 Gloucester Street, Ottawa, Ontario K1R 5E9.

Telephone: (613) 238-4256. 


\section{Report on Illegal Immigrants in Canada}

"Tllegal immigration in Canada is a major problem that is growing every day. Something must be done about it."

The report on illegal immigrants presented to Employment and Immigration Minister Lloyd Axworthy by the Canada Employment and Immigration Advisory Council has found that illegal immigration in Canada is a major problem. The Council was unable to arrive at an exact figure for the number of illegal immigrants in Canada due to a lack of precise data; however, the Council believes that the number 200,000 , often used as an estimate, is conservative.

The solutions to Canada's illegal immigration problem proposed by the Council include the following:

1. Curative Measures: Illegals presently in Canada should be given legal resident status after a phased, six-year probationary program administered by the government with the help of nongovernmental community agencies. The Council feels that such measures would be the most realistic and humane way to deal with illegal aliens in Canada. However, the Council has made a clear distinction between this program and an unconditional amnesty, which it feels is ineffective and counter-productive.

2. Preventive Measures: To prevent a further build-up of illegal immigrants, the Council advocates tighter control at points of entry as well as stiffer enforcement measures within Canada as follows: the establishment of an entry and exit control system at border points; the active seeking out of illegal immigrants; and a more strict application of the the Immigration Act for employers who knowingly hire illegals.

Canada. Employment and Immigration Advisory Council
A Study Document of Principles on the Issue of Undocumented Aliens came out of a conference on undocumented aliens convened by Lutheran Immigration and Refugee Service in November 1978 and followed by a lengthy study process. Adopted by the LIRS standing committee in September of 1980, the document provides pertinent background material on undocumented persons or "illegal aliens," a theological framework for discussing the issue and public policy recommendations for improving U.S. immigration law and policy. It can be obtained by writing to the Lutheran Council in the United States of America, 360 Park Avenue South, New York N.Y. 10010.

\section{Canada Makes Unilateral Declaration Against Torture}

The Honourable Charles Lapointe, Minister of State (External Relations), announced on December 17, 1982 that the Government of Canada has decided to make a unilateral declaration of its continued compliance with the "Declaration on the Protection of All Persons from Being Subjected to Torture and Other Cruel, Inhuman or Degrading Treatment or Punishment".

The declaration, conveyed in a note addressed to the Secretary General of the United Nations, confirms solemnly the intention of the Canadian authorities to continue to act in conformity with the Declaration. This moral commitment entails no change in present Canadian law or practice which continue to be consistent with the principles contained in the Declaration of the United Nations.

The UN Declaration against torture, which was adopted by the General Assembly on 9 December 1975, does not include legally binding obligations for States. To date, over 30 governments, including the Canadian Government, have declared unilaterally that the competent authorities within their respective territories intend to act in conformity with the provisions contained in the Declaration.
The Government of Canada intends, in addition, to continue to work within the UN Commission on Human Rights for the early completion of the drafting of an "international convention against torture and other curel, inhuman or degrading treatment or punishment (under consideration in Geneva since 1978). Canada believes it is important that the international community provide itself with the legal instruments necessary for the effective suppression of the practice of torture in the world.

\section{Minister of Employment and Immigration Appoints Special Advisor}

Employment and Immigration Minister Lloyd Axworthy announced on December 21, 1982, the appointment of Mr. W.G. Robinson as a special advisor to study and analyse problems related to people living in Canada without official status, as well as those seeking unauthorized entry into this country. The announcement is in response to the recent report on illegal immigrants prepared by the Canada Employment and Immigration Advisory Council.

\section{***}

\section{Vietnamese Community Petitions Canadian Government}

Members of the Vietnamese community are planning to get signatures for a petition addressed to the Canadian Government and the United Nations High Commissioner for Refugees to ask the Canadian Government and UNHCR to intervene in favour of Vietnamese refugees now being detained in concentration camps in Thailand so that the Thai Government will grant them the status of refugee (according to the Geneva agreements) and allow UNHCR, the Red Cross, and settlement countries' immigration officers to visit and interview them 
Sanctuary: An African Epic focuses on the efforts made by governments and UNHCR to find durable solutions for refugees on that troubled continent. The 28-minute production, shot in 1982 in Somalia, Sudan, Tanzania and Zimbabwe, is narrated by Orson Welles, and was filmed by Dick Young Productions of New York City.

$$
* * *
$$

Rwanda Influx examines the recent exodus from Uganda and outlines the international response to the emergency.

***

Nueva Esperanza is a look at the Salvadorean refugees in Honduras and their movement away from the border areas. This 16-minute production is narrated by actor James Mason.

*******

These films may be obtained by contacting the UNHCR.

$$
\begin{gathered}
\text { Life Begins in January } \\
\text { a film }
\end{gathered}
$$

produced by Jean Dansereau in co-operation with the UNHCR

the International Committee of the Red Cross

the Thai Red Cross

and UNICEF

Life Begins in January was filmed in the refugee camps such as Khao-I-Dang (the largest refugee camp in the world) along the Khmer/Thai border. The film reveals firsthand how the refugees would suffer or perish without the massive aid provided by UNICEF, the International Red Cross, the World Food Program and other similar organizations. Transcending the horror of genocide effected by the Vietnamese troops, who in 1979 invaded and occupied Kampuchea and forced the Khmer out of their own country, is the courage of a people who, despite the uncertainty of their future, persist in keeping alive their 2,000-year-old traditions.

$16 \mathrm{~mm}$ Colour; $58 \mathrm{~min} .3 \mathrm{sec}$; $16 \mathrm{~mm}$ : 106C 0180 049; Video: 116C 0180049

This film is distributed by the National Film Board of Canada, P.O. Box 6100, Montreal, Quebec H3C 3H5.

\section{Seeds of Liberty a film}

Produced by Catalyst Films for the Maryknoll Order.

In November, 1980, four North American missionaries were murdered in El Salvador.

Awarded first prize in 1981 by the International Jury in Oberhausen, Seeds of Liberty depicts the social and economic conditions that frustrate the people of El Salvador and the role of the army in terrorizing the whole population. The film reveals the people's will and desire to seek and fight for human dignity and a just society.

Bishops, priests, nuns and lay church people both in the U.S. and El Salvador talk frankly of the repression and the U.S. government's support for a corrupt and oppressive military regime. At the same time, President Jose Napoleon Duarte and General Jose Guellermo Garcia offer their solutions to the camera. Murrat Williams, former U.S. Ambassador to El Salvador (1961-64), makes a plea for an end to U.S. military support of the Duarte regime and calls for a Salvadoran solution to the current situation.

Available from the Development Education Centre, 427 Bloor Street West, Toronto, Ontario. (416) 964-6560.

\section{UNHCR Slide Kits}

The UNHCR now has available three slide-tape kits geared to secondary school students. The three are entitled, "International Assistance - How It Works," "A Trauma of Our Times" and "Refugees - A Historical Perspective." Each package contains 50 to 60 colour slides, a cassette tape to accompany the slides, and a number of workbooks for use by both students and teachers. They are available for purchase at U.S. $\$ 55.00$. More information about the slide kits may be obtained from Doug MacDonald, Public Information Officer, United Nations High Commissioner for Refugees, 280 Albert St., Suite 401, Ottawa, Ontario K1P 5G8. 


\section{$=$ Books $\overline{=}$ World News Received}

The Refugee Documentation Project has recently acquired the following books:

Transnational Legal Problems of Refugees, The Michigan Yearbook of International Legal Studies. 1981. Clark Boardman Company Ltd.

$$
\text { ** * }
$$

Struggle and Hope: The Hungarian Canadian Experience. N.F. Dreisziger. McClelland and Stewart Ltd. 1982.

$$
\text { *** }
$$

For a Better Life: A History of the Croations in Canada. A.W. Rasporich. McClelland and Stewart Ltd. 1982.

$$
\text { ** * }
$$

Global Refugee Policy: The Case for a Development Oriented Strategy. Charles B. Keely. The Population Council, N.Y. 1981.

$$
\text { *** }
$$

The Smallest Pawns in the Game. Peter Townsend. Little, Brown and Co. 1980.

$$
\text { ** * }
$$

The Refugee Documentation Project at York University is concerned with acquiring and preserving archival materials pertaining to refugees in and from all parts of the world. (The Project's library is open between 10 a.m. and 5 p.m. on weekdays.) Donations of documents, papers, reports or other library materials are encouraged.

If you have worked with refugees or have conducted research on refugees or refugee-related issues, please write and tell us about your work. A function of the Project is to create an index of Canadian individuals and organizations concerned with refugees in order to establish a referral network among people needing information on refugees. Another mandate of the Project is to carry out crisis field research.

Further information may be obtained by writing to C. Stephens, Refugee Documentation Project, York University, 4700 Keele Street, Downsview, Ontario M3J 2R6. Telephone (416) 667-3639.

\section{Statue "Refugee" Unveiled}

The Statue "Refugee" by the Argentinian Sculptor, Adolfo Perez Esquivel, who was awarded the Nobel Peace Prize in 1980, was unveiled on December 13, 1982 at the headquarters of the office of the United Nations High Commissioner for Refugees in Geneva.

\section{Soviet Generosity}

With one exception, the Soviet Union has never contributed a single kopeck to any of the many international refugee relief efforts.

That exception was in 1971 when Moscow gave some modest help to the UNHCR's aid program for the 10 million

Bengalis who fled to India from what was then East Pakistan.

Edward Girardet, from Christian Science Monitor Reprints, "Refugee Crisis."$$
\text { *** }
$$$$
1982 \text { Migration Totals }
$$

In December, 7,570 migrants were processed and moved, bringing the total for the year to 140,500 . The number of Indochinese refugees accepted by the resettlement countries declined from 157,900 in 1981 to 86,225 in 1982 , but more Vietnamese $(9,770$ against 8,530$)$ were able to emigrate legally under the Orderly Departure Program. Movements under the other refugee migration programs increased from 43,420 to 49,500, mainly from Eastern Europe.

A slight decrease was also registered in the emigration of nationals from Western Europe $(4,800$ against 5,700), but the number of persons who went to Latin America was higher, in particular under the Return of Talent program. Migration movements were organized from 88 emigration countries to 106 immigration countries.
Also of note was the drop in departures of Soviet Jews from 9,460 in 1981 to about 2,700 in 1982, and in departures of Armenians and family reunion cases from the USSR from 2,450 to 400 . About 2,000 Romanian migrants transited through Italy. The number of Polish asylum seekers resettled by ICM (Intergovernmental Committee for Migration) increased from 5,020 in 1981 to 15,335 in 1982, the latter including 640 under a special program for former detainees authorized to emigrate with their families.

$$
\text { *** }
$$

- 81 Jews from the Soviet Union arrived in Vienna during January, the lowest monthly total since this emigration started in 1971.

- 600 Polish asylum-seekers from Austria, Germany, and Italy moved during January brought to 21,500 the total of Poles who have been resettled since mid-1981.

- 4,600 Indochinese refugees ex-Asia were moved for permanent resettlement; 2,975 others were transferred to the Refugee Processing Centre at Galang, Indonesia (2,530 from Thailand).

- 29 Vietnamese refugees of Chinese ethnic origin transited through Hong Kong en route from the People's Republic of China to final destinations in Austria, France, the United Kingdom and the U.S.A.

- 50 Amerasian children (the fourth group) were moved from the Socialist Republic of Vietnam to the U.S.A.

- 16 handicapped refugees plus 30 family members from Malaysia were moved to Finland, thereby completing the transfer to that country of a total of 21 handicapped refugees and 34 family members.

Intergovernmental Committee for Migration Monthly Dispatch, Jan. \& Feb. 1983. 


\section{Refugees of Concern to UNHCR?}

\begin{tabular}{lr}
\multicolumn{2}{c}{ AFRICA } \\
ALG & 167,000 \\
ANG & 93,600 \\
EGY & 5,500 \\
BOT & 1,300 \\
BUR & 214,000 \\
CAM & 3,400 \\
CAR & 4,000 \\
DJB & 31,600 \\
ETH & 11,000 \\
KEN & 4,000 \\
LES & 11,500 \\
NOR & 500 \\
NIG & 100,000 \\
RWA & 18,000 \\
SEN & 4,000 \\
SOM & 700,000 \\
SUD & 627,000 \\
SWA & 5,800 \\
UGA & 113,000 \\
TAN & 174,000 \\
ZAI & 325,000 \\
ZAM & 58,300 \\
\hline TOTAL & $2,672,500$
\end{tabular}

Total by continent Total other countries Grand Total
ASIA \& M/EAST

\begin{tabular}{lr} 
CHINA & 268,700 \\
HK & 10,800 \\
INDIA & 4,600 \\
INDON. & 13,500 \\
IRAN & $1,600,000$ \\
JAP & 1,900 \\
LAOS & 3,500 \\
LEB & 3,100 \\
MACAU & 1,100 \\
MAL & 102,200 \\
PAK & $2,743,000$ \\
PHIL & 14,600 \\
VTN & 28,500 \\
THAI & 182,200 \\
\hline TOTAL & $4,977,700$
\end{tabular}

LATIN AMERICA

ARG $\quad 12,300$

BELISE $\quad 7,000$

BRAZIL $\quad 5,400$

CHILE 2,500

C/RICA $\quad 15,000$

CUBA $\quad 2,000$

DOM R $\quad 5,000$

GUAT $\quad 50,000$

HOND 29,000

MEX $\quad 146,000$

NIC 22,500

PAN $\quad 1,500$

PERU $\quad 500$

\begin{tabular}{lr} 
VEN $\quad 500$ \\
\hline TOTAL $\quad 299,200$
\end{tabular}
N. AM. \& EUROPE

AUL $\quad 317,000$

AUS $\quad 30,000$

BEL $\quad 22,000$

CAN $\quad 353,000$

DEN $\quad 1,800$

FRG $\quad 100,000$

FRA $\quad 150,000$

GRE $\quad 4,000$

IT 13,500

USA $\quad 1,003,000$

NETH $\quad 13,000$

NZ $\quad 10,600$

NOR $\quad 6,000$

PORT $\quad 7,600$

ROM $\quad 1,000$

SPAIN 21,900

SWE $\quad 20,000$

SWIT $\quad 40,000$

TUR $\quad 1,200$

UK $\quad 146,000$

YUG $\quad 1,100$

TOTAL $\quad 2,262,700$

Source: UNHCR

\section{Editor's Note:}

The figures contained in this chart are quite misleading. For example, the numbers of refugees cited for Australia, Canada and the United States, among others, include all refugees settled since the Second World War who are now citizens of their adopted countries of residence. On the other hand, some countries such as Israel are not even mentioned. The figures given for Lebanon are inaccurate.

When are we going to develop statistics not based on category mistakes, omissions and distorted data? Otherwise the cry that there are ten (twelve? fourteen?) million refugees in the world is a fraud. 